\title{
TTR
}

Traduction, terminologie, re?daction

\section{Translation and Historical Stereotypes: The Case of Pedro Cieza de León's Crónica del Perú}

\author{
Juan J. Zaro
}

Volume 13, numéro 1, 1er semestre 2000

Idéologie et traduction

Ideology and Translation

URI : https://id.erudit.org/iderudit/037396ar

DOI : https://doi.org/10.7202/037396ar

Aller au sommaire du numéro

Éditeur(s)

Association canadienne de traductologie

ISSN

0835-8443 (imprimé)

1708-2188 (numérique)

Découvrir la revue

Citer cet article

Zaro, J. J. (2000). Translation and Historical Stereotypes: The Case of Pedro

Cieza de León’s Crónica del Perú. TTR, 13(1), 113-135.

https://doi.org/10.7202/037396ar
Résumé de l'article

Traduction et stéréotypes historiques : l'exemple de la Crónica del Perú (1553) de Cieza de León - La Crónica del Perú (volumes I et II) de Pedro Cieza de León (1553) offre l'une des descriptions les plus méthodiques et objectives de la conquête espagnole de l'Amérique. L'ouvrage a d'abord été traduit vers l'anglais par le capitaine John Stevens en 1709, puis par Sir Clements R. Markham en 1864 pour la Société Hayklut et finalement par Harriet de Onís, en 1959. Toutefois, aucune de ces traductions ne rend justice à l'oeuvre remarquable de Cieza. Alors que les deux premières traductions comportent de nombreuses erreurs et omissions, admises ou non, comme l'ont signalé Diffie, 1936; Bernstein et Diffie, 1937 et Pedro R. León, 1971, la dernière, en voulant amalgamer les deux volumes, prête à confusion et comporte aussi coquilles et inexactitudes.

Cet article tente de démontrer comment les traductions anglaises de la Crónica, par des modifications malencontreuses ou intéressées visant à supprimer l'objectivité de l'oeuvre de Cieza, ont contribué à renforcer les stéréotypes qui ont donné naissance à la « légende noire » de la conquête espagnole du Nouveau Monde. Des stéréotypes, qui, à la lumière des exemples cités, auraient peut-être besoin d'être revus.
Tous droits réservés @ C TTR: traduction, terminologie, rédaction — Les auteurs, 2000 ce document est protégé par la loi sur le droit d'auteur. L'utilisation des services d'Érudit (y compris la reproduction) est assujettie à sa politique d'utilisation que vous pouvez consulter en ligne.

https://apropos.erudit.org/fr/usagers/politique-dutilisation/ 


\title{
Translation and Historical Stereotypes: The Case of Pedro Cieza de León's Crónica del Perú
}

\author{
Juan J. Zaro
}

The Crónica del Perú written by Pedro de Cieza de León (1521?-1554), a chronicle that describes the conquest and colonization of Peru by the Spaniards in the first half of the sixteenth century, is one of the most objective accounts of the Spanish conquest of America. It follows a systematic plan, explained by the writer in his preface, according to which each of its four parts is assigned a specific subject: the first is a personal account of his journey from Panama to Potosí, and of his observations of the early colonization of Peru; the second is a history and description of the Inca Empire; the third is about the conquest of Peru and the fourth, divided into five sections or "books", is a chronicle of the civil wars fought between the Spaniards in Peru right after the conquest. The Crónica is also very well written: Cieza's balanced mixture of observation, description, narrative and personal comments has been paralleled to that of Bernal Díaz del Castillo, Cortés's companion in the conquest of Mexico, whose Historia de la conquista de Nueva España is considered the best piece ever written on the conquest ${ }^{2}$.

\footnotetext{
' Pedro de Cieza de León was born in Llerena (Badajoz, Spain) around 1521. He died in Seville in 1554, after having travelled in South America from 1535 to 1551. He participated in several expeditions in what today are Peru and Bolivia, and was at the service of Captains Jorge Robledo, Sebastián de Belálcazar, and Pedro de La Gasca. He is considered to be the "Prince of Chroniclers" of the Spanish Conquest of the New Land.
} 


\section{Spanish editions and translations in English}

The only part of the Crónica published in Cieza's lifetime was the first (1553), which had four editions in Spanish and five translations into Italian in the sixteenth century. The second was not to be published until 1880 in Madrid, after the manuscript, which was believed to be lost, was located in El Escorial by the Spanish scholar Marcos Jiménez de la Espada. Fifteen chapters of the third part, which was also believed to have been lost forever, were discovered and published by the Peruvian scholar Rafael Loredo in the newspaper El Mercurio Peruano in Lima from 1946 to 1958 . In 1974, another nine chapters of this third part were found and published by the Spanish scholar Carmelo Sáenz de Santamaría. Finally, of the five books of the fourth part (La Guerra de las Salinas, La Guerra de Chupas, La Guerra de Quito, La Guerra de Guarina and La Guerra de Xaquixahuana), the first three were published in Madrid in 1877, 1881 and 1909 respectively, but the last two are still lost, and there are doubts as to whether they were really written at all (Ballesteros, 1984, p. 30). The most recent Spanish editions of the Crónica have been carried out by Carmelo Sáenz de Santamaría (Obras completas, 1985) for the CSIC (Spain's National Council for Scientific Research), and Manuel Ballesteros (Crónica del Perú, 1984; El señorío de los incas, 1985) and Carmelo Sáenz de Santamaría (Descubrimiento y conquista del Perú, 1986) for Historia 16, a publisher specialising in historical books. The Pontificia Universidad Católica del Perú also published Cieza's complete works from 1983 to 1992.

The first part of the Crónica was first translated into English in 1709 by Captain John Stevens, translator of French, Portuguese and Spanish, with the long title The Seventeen Years Travels of Peter de Cieza through the Mighty Kingdom of Peru and the Large Provinces of Cartagena and Popayan in South America from the City of Panama, on the Isthmus, to the Frontiers of Chile. In 1864, Sir Clements R. Markham

\footnotetext{
${ }^{2}$ In his writings, Cieza introduced words so far unknown to the Spanish language, like "aguacate" (avocado), "barbacoa" (barbecue) and "hamaca" (hammock). For a complete list of the words introduced by Cieza and other chroniclers (Cortés, Díaz del Castillo, Cabeza de Vaca, etc.) we refer the reader to Martinell Gifre (1988).
} 
retranslated it for the Hakluyt Society of London, with the title The Travels of Pedro de Cieza de León Contained in the First Part of his Chronicle of Peru. Finally, a third partial translation by Harriet de Onís, edited by Victor Wolfgang von Hagen with the title The Incas of Pedro Cieza de León, which is actually a conflation of the first two parts into one single book, was published by the University of Oklahoma Press in 1959.

The second part was first translated into English by Sir Clements R. Markham in 1883, also for the Hakluyt Society, with the title The Travels of Pedro de Cieza de León Contained in the Second Part of his Chronicle of Peru, and then by de Onís as The Incas of Pedro Cieza de León (1959). The third part, the most recently discovered, has just been translated into English by Alexandra Parma Cook and Noble David Cook (1998), in what is the latest translation of the Crónica into English. Finally, the three books of the fourth part were translated by Sir Clements R. Markham for the Hakluyt Society with the titles The War of Quito (1913), The War of Chupas (1918) and The War of Las Salinas (1923).

But the Crónica does not seem to have been particularly fortunate in its English translations. According to several critics (Diffie, 1936; Bernstein and Diffie, 1937; Von Hagen, 1959; León, 1971; Child, 1992), none of the first three translations does justice to Cieza's magnificent work. Bailey W. Diffie (1936, p. 96) is especially critical of Markham's translation, which he considers to be "badly rendered" for three different reasons: "(1) generally incorrect rendition of the Spanish text into English; (2) acknowledged omissions; (3) mistranslations of important passages and unacknowledged omissions". After going over examples of these mistakes, Diffie concludes his article as follows:

It is a disappointment to find a work of such reputation to be deficient in so many respects. While it may be argued that the scholar will always go to the source, or as near the source as he can get, such an argument does not suffice to condone a poor translation. Originals are not always available. Frequently, only a translation can be had. The matter becomes even more serious when the tendency of the omissions and mistranslations is noted; many of them were distinctly unfavourable to the Spanish. None of the errors placed the Spaniards in a more favourable light (1936, p. 103). 
In a further article (1937), Bailey W. Diffie and Harry Bernstein widen the scope of their critique to other translations by Markham of well-known Spanish chroniclers (Francisco de Xerez, Garcilaso de la Vega and Pedro de Sarmiento de Gamboa). They justify their severe comments on the grounds that the extensive use of the Markham translations by present-day students is leading to an accumulation of errors, and makes further attention to Markham justifiable (p. 546).

Victor Wolfgang von Hagen, in the preface to his edition of The Incas of Pedro de Cieza de León, after accusing the available Spanish editions of execrable scholarship (1959, p. vii), criticises the Stevens translation in the following terms:

The alembic was poor; the chapters are castrated and whole portions telescoped together in the most arbitrary fashion. Moreover, the editor ignored the authentic illustrations that appeared in the original Cieza and made his own in high-blown sententious fantasy: the edition's only merit is that it was the first in English of the "Prince of Chroniclers" (1959, p. viii).

$\mathrm{He}$ is also critical of the Markham translation, though less severely, on account of his omission of entire sections which he found "unfit for translation", and, furthermore, written in a style that is often broken and limping in its threadbare prose (1959, p. viii).

Finally, Pedro R. León (1971) analyses the three English translations of the Crónica, paying special attention to the translation done by John Stevens in 1709. Leon describes the omission and conflation of chapters, the translation mistakes and the illustrations that Stevens included in the edition. In the case of the Markham translation, he emphasises the overt suppression of all passages about the sexual and cannibalistic habits of the Indians. In the third place, León criticises the translation made by Harriet de Onis and edited by Von Hagen, and especially their decision to combine the two parts into one. He argues that the substantial differences in tone and style between the first and the second part, which Cieza had carefully established, are obliterated in this edition. In this respect, he quotes the following anonymous review on The Incas of Pedro de Cieza de León which had appeared in The Times Literary Supplement on December 4, 1959: 
[...] And it is with regret that we must record that in spite of the distinguished credentials of editor, translator and university press, the present version of parts I and II fall far short of the standard. Cieza has his "langueurs" and his repetitions, but the drastic liberty here taken in an attempted conflation of the two parts, with constant reshuffling of chapter from one to the other, does not solve them, and adds to its own confusion.

But although all critics judge the translations in a rather severe tone, only two of them (Diffie, 1936; Child, 1992) openly relate the quality of the translations, especially Markham's, to ideological issues, in this case the diffusion of the Leyenda Negra (Black Legend) against Spain.

The Black Legend was an attempt by England, Holland and France to portray Spain, and Spanish enterprises like the conquest of the New World, as those of a cruel, exploitative and fanatical power. As Child explains:

The purpose was to diminish the achievements of the Iberians in America and justify the Northern Europeans in their quest to take the Spanish possessions, or the riches they generated, away from them. It was a massive propaganda effort sustained over a period of many years, and which continues to have impact in certain prejudicial attitudes against Hispanics today (1992, p. 95).

One of the main reasons for the Black Legend was the so-called "Counter-Reformation" carried out by the Roman Catholic Church against Europe's emerging Protestant churches, and especially against those in England and Flanders, of which the Spanish King Philip II was a staunch champion. Philip tried, unsuccessfully, to fight the Protestant reformation by means of military operations like the Armada Invencible, which was sent to invade England in 1588 with the purpose of restoring the Catholic faith and depose Queen Elizabeth I, and the wars, followed by cruel repression, against the rebel army in the Low Countries, then a province of the Spanish Empire. Conversely, the king's enemies counterattacked using events like the imprisonment and death of Philip's son, Prince Don Carlos, or the public denunciation of the Spanish abuses in America made by Bartolomé de Las Casas in his tract Brevíssima Relación de la Destrucción de las Indias (1547), to activate anti-Spanish propaganda. 
Works like the Apology of the Dutch leader William of Orange (1580), or Relaciones (1598), written by Philip's secretary Antonio Perez, who fled into exile in England, contributed to the spread of the Black Legend against Philip II and Spain in general. Nineteenth-century plays like Schiller's Don Carlos, and operas like Beethoven's Fidelio or Verdi's Don Carlos, reinforced the stereotype of the king as an intolerant and cruel human being and of the Spaniards as passionate and unscrupulous people.

The works of French and British historians like Ferdinand Braudel, Henry Kamen, or Geoffrey Parker in the twentieth century, have slowly restored the image of King Philip, a Renaissance prince whose decisions reflect the contradictions of his time. To be sure, his policies were not altruistic, but the consistent emphasis on the negative aspects of his reign exerted by the Black Legend have distorted his real significance and ignored his achievements, which were also remarkable. The Spanish historian Ricardo Garcia Cárcel (1998, p. 33) suggests that even Spanish historiography has indirectly focused on these negative aspects owing to its constant obsession with the Black Legend, to which it has devoted an unhealthy attention through the nineteenth and early twentieth centuries. Garcia Cárcel attributes this obsession to the "victimisation" complex of the Spanish people in relation to foreign opinions and values:

Y es que hay que tener presente que en lo que llamamos leyenda negra, ha contado tanto como el flujo de opinión negativa y hostil a nuestro pais, ese complejo victimista un tanto angustioso, arrastrado durante siglos, de agónica dependencia de la opinión que los extranjeros han tenido de nosotros (1998, p. 33).

The historical stereotype of the Spanish conquest of America, derived from the Black Legend, is now being revised both by modern Spanish and Anglo-Saxon historiographers. Among the latter, the American scholar Gesa Mackenthun (1997, p. 71) has highlighted the "translational" character of the American conquest, and the attempts of the nationalistic discourse of early English colonialism to keep out any Spanish presence. One of their methods was to establish a set of differences between Spanish and English colonial systems, stressing the barbaric character of the former. But the effects of the European conquest on the indigenous population were shocking and devastating not only in 
the Spanish Empire. As a matter of fact, there were soon voices in Spain demanding a humanitarian treatment of the Indians. In this sense, Mackenthun (1997, p. 14) points out how "it is important to note that the intellectual world of sixteenth-century Spain was crucially concerned with the legitimacy of conquest and thereby set high standards for other nations".

The role of translation in the spreading of the Black Legend is, so far, very little known. Child (1992, p. 95) quotes two examples. One is the already mentioned Brevissima Relación de la Destrucción de las Indias by Las Casas (1547). This tract, which provoked a great response on Spanish society, causing the Crown to institute reforms, was immediately translated into Latin, English, French, German and Dutch. The English translation of 1606 carried, significantly, the subtitle Popery truly Display'd in its Bloody Colours: Or a Faithful Narrative of the Horrid and Unexampled Massacres, Butcheries, and all manner of Cruelties, that Hell and Malice could invent, committed by the Popish Spanish Party on the Inhabitants of West India... ${ }^{3}$ The other example is Pedro de Cieza de León's Crónica del Perú, and especially the Markham translation. In what follows, I shall discuss the translations of the first part of the Crónica, together with some relevant paratextual elements like the prefaces written by Stevens, Markham and Von Hagen.

\section{The Stevens translation}

Captain John Stevens (1666?-1726), a prolific translator of Spanish, French and Portuguese historical and literary works into English - his best known versions from Spanish are Avellaneda's apocryphal Quixote, Quevedo's works, and the famous picaresque novel La picara Justina, whose main character is a woman -, translated Cieza's first part of the Crónica in 1709. The book included 94 out of the 121 original chapters, plus a three-page dedication "to Sir Edmund Poley of Badley in the county of Suffolk, Esq.", a translator's preface, a final index and several illustrations showing idealised pictures of the aborigines which have nothing to do with Cieza's descriptions. However, Stevens omits Cieza's own preface.

${ }^{3}$ As cited in Hubert Herring, A History of Latin America (1965, pp. 176-177). 
In his preface, Stevens openly declares his admiration for Cieza, and briefly describes the hardships that the Spaniards had to endure in the process of discovering and colonising the first territories in America. The charges of bloodshed and cruelty to the Indians are qualified with the following explanation:

To do all Men right, I must declare that all the Spaniards were not guilty of this misusing the Indians; for I have often seen, and can affirm of my own knowledge, that they were kindly treated by good and moderate men, who when they happened to be sick, would bleed and serve them with their own hands, and perform other acts of Charity and Humanity towards them at other times $(1709$, p. 2).

According to Stevens, the impunity of these acts was suddenly brought to an end when the king of Spain decreed the establishment of a government and judicial system in America:

The King being informed of the great oppression the Indians lay under, and considering how much it concerned the honour of the Government to abolish all such wicked practices, was pleased to appoint Viceroys, and Sovereign Courts, with Presidents and judges, filling all those places with men of Worth and Integrity; by which means the Indians seem to be rais'd again from the Grave, and their miseries have ceas'd $(1709$, p. 2).

As shown above, Pedro L. León (1971, p. 201) compared the Stevens translation with the source text, and described in great detail the different organisation, the mistakes, compressions and, particularly, the omissions of whole sections in the target text, which he grouped into three main types: (1) the customs of the Indians, in particular their burial practices; (2) the references to the Devil and the efforts of the Spanish missionaries to spread the word of God; (3) Cieza's moralising digressions about the reasons for the conquest and the Spaniards' greed.

One of the reasons for these omissions was Stevens' "impatient" tone, detected by León (1971, p. 201), which perhaps results from conceiving his translation more as a travel book than as a chronicle. Robert H. Williams also commented on this impatience in his article about the manuscript document of Stevens' translations into Spanish deposited in the British Museum. In this document, Stevens made notes about his 
own books which "often indicate an impulsive reaction. In general, his hasty estimates bear the severity of an impatient nature so that they cannot be relied upon very far" (1936, p. 166). Williams concluded that Stevens translated for profit, and that his only purpose was to find saleable material.

Other traits, of an ideological nature, may also be detected in his translation strategies. The omission of all references to the Devil, whose influence is constantly quoted by Cieza as a cause for evil, and to the esoteric burial practices of the Indians, seems to originate in Protestant attitudes shared also by Markham who, in the "Introduction" to his translation, comments on Cieza's Catholic beliefs, and concludes that "he was so steeped in the superstition of his age and country that all the simple rites of the Indians appeared to him to be the work of the devil, and in every harmless ceremony he saw the cloven feet" $(1864, \mathrm{p}$. lvi). Markham, however, does not omit these references.

\section{The Markham translation}

The clergyman Sir Clements Robert Markham (1838-1919), honorary secretary and president of the Hakluyt Society, translated the first part of the Crónica del Perú in 1864, the second part in 1883, and the fourth, fifth and sixth parts (the Civil Wars), in 1918. The Hakluyt Society had been founded in 1846 and named in honour of another English clergyman, Richard Hakluyt the younger (1552?-1616), an editor of travel writings ${ }^{4}$. Its object was the advancement of education by the publication of scholarly editions of records of voyages, travels, and other geographic material of the past.

Markham, who came from a highly regarded clerical family, had spent several years in the navy and travelled in Peru to explore the eastern slopes of the Andes. Then he entered the civil service, working in the

\footnotetext{
${ }^{4}$ Hakluyt was not an explorer himself. He was the first lecturer on geography and cosmography at Christ Church, Oxford, and wrote books like Principal Navigations, Voyages and Discoveries of the English Nation (1598-1600) with the purpose of promoting English exploration and colonization. The "colonial program" contained in this book has been recently discussed by Gesa Mackenthun (1997, pp. 22-48).
} 
India Office, and performing various administrative functions in India. In 1875 he went on an Arctic expedition to Greenland. He also held key positions in the Hakluyt and Royal Geographical Societies, from which he lent decisive support for England's expedition to Antarctica in 1901. He was a prolific translator of Spanish classical travel chronicles of the sixteenth and seventeenth centuries.

In the "Introduction" to his translation, Markham clearly establishes his position regarding the Spanish conquest of America and the moral stature of the "conquistadores":

Among the leaders of these expeditions there were some honourable knights, with courteous manners and cultivated minds, such as Diego de Alvarado, Garcilaso de la Vega and Lorenzo de Aldana. But the majority were either coarse and avaricious adventurers, or disappointed courtiers... $(1864$, p. ii).

The figure of Pedro de Cieza de León is, however, carefully separated from this "majority". Like other critics of his work, Markham praises Cieza's personal qualities both as a human being and as a chronicler of the conquest with the following words:

We may gather from his writing that he was humane and generous in his dealings with the Indians, indignant at the acts of cruelty and oppression which he was forced to witness, that he was in the habit of weighing the value of conflicting evidence in collecting his information, and that fuller reliance may be placed on his statements, than upon those of almost any other writer of the period $(1864$, p. x).

As shown above, Bailey W. Diffie disqualifies the Markham translation for three different reasons. Of these, the acknowledged omissions are probably the most interesting from a translatological point of view. Markham warns the reader that something is missing with the plea that it is "unfit for translation", and he either omits the paragraph or chapter completely (e.g., paragraph on page 225 or chapter LXIV), or provides the Spanish version without translating it (e.g., 1864, pp. 83, 152). All these omissions have sexual overtones, like the line missing in page 83, in which the Spanish original text is provided in a footnote: 
Muchos tienen con la una mano la vasija con que están bebiendo, y con la otra el miembro con el que orinan. [Literal translation: Many of them hold the pot from which they are drinking with one hand, and their urinating member with the other].

But the most noteworthy omission is chapter LXIV, which deals with the priestly pederasts who were common, Cieza tells us, among the Indians of both the mountains and the valleys. In 1886, Sir Richard Burton, in the Terminal Essay, which followed his translation of The Book of the Thousand and One Nights, included a section on Pederasty ${ }^{5}$, in which he explicitly criticised this omission:

We have authentic details concerning Le Vice in Peru and its adjacent lands, beginning with Cieza de León, who must be read in the original or in the translated extracts of Purchas (vol. V, 942), not in the cruelly castrated form preferred by the Council of the Hakluyt Society (1886, p. 82).

This kind of manipulation seems to have been common in Victorian translation practices. One of the initial norms followed literally by translators like Markham consisted of the omission of all references of a sexual nature. References to "perversions", like those described in chapter LXIV, were completely left out, while others of a lesser nature were untranslated, although the reader was given the possibility of reading the original.

From an ideological point of view, the translation strategies followed by Markham served the purpose of enhancing a historical stereotype unfavourable to the Spanish conquest of America. As shown above, the makers of the Black Legend had already used documents like Las Casas' Brevíssima Relación... to reinforce anti-Spanish propaganda in Europe. Markham does the same, three centuries later, at a time when

${ }^{5}$ The symbolic significance of the references to sodomy described by the chroniclers of the Spanish Conquest is analyzed, among others, by Jonathan Goldberg in Sodometries, 1992, pp. 182-188. 
the British Empire was expanding, and British methods of colonization had to be justified by contrasting them with others. As Bernstein and Diffie have shown (1937), Markham followed the same strategies in other translations, namely to mistranslate passages and not to acknowledge omissions. Among the second, Markham systematically omitted the favourable comments on the Spaniards expressed by Cieza de León:

1. "Toda la más de esta ciudad está poblada, como ya dije, de muchos y muy honrados mercaderes" (Cieza, 1984, p. 75)

"The city is inhabited by many merchants" (Translation by Markham, 1864, p. 17)

[Literal translation: The city is inhabited, as I said above, by many, and very honest, merchants"].

2. "Y gobernándolo él todo por su persona y por los tenientes que él nombraba, según dicen muchos conquistadores de esas ciudades, el tiempo que él estuvo en ellas miró mucho el aumento de los naturales y mandó siempre que fueran todos bien tratados" (Cieza, 1984, p. 171)

"He governed them all, either himself or through lieutenants whom he named, and, as is said by many conquerors in these parts, he ordered that the natives should be well treated during the whole time that he was in command" (Translation by Markham, 1864, p. 123)

[Line omitted: He strove for the prosperity of the native inhabitants]

The omissions are also intended to belittle the actions and behaviour of the Spaniards in Peru, as narrated by Cieza. Thus, Diffie (1936, p. 98) explains that the systematic omission of the words poblado (populated) $y$ despoblado (unpopulated) is of an ideological nature. Markham is trying to give the impression that the depopulation of vast areas of Peru was owing to the Spaniards, and not to wars between the Indians before the conquest. He includes the following example, in which Cieza considered cannibalism a more important factor in the decrease of the Indians than war with the Spaniards, whereas Markham puts the blame on the Spanish:

3. "Este río hacia la ciudad de Cali fue primero poblado de grandes pueblos, los cuales se han consumido con el tiempo y con la guerra que les hizo el capitan Belálcazar, que fue el primero que los descubrió y 
conquistó, aunque el haberse acabado tan breve ha sido gran parte, y aun la principal, su mala costumbre y maldito vicio, que es comerse unos a otros" (Cieza, 1984, p. 382)

"The banks of this river were once very populous, but the people have been extirpated by time and by the war which they waged with Captain Belálcazar, who was the first to discover and conquer them. Although he was one cause of their rapid destruction, yet another cause of it [literal translation: the main cause of it] was their evil custom and accursed vice of eating each other" (Translation by Markham, 1864, p. 108)

Even though the cruelty of the Spaniards was incontrovertible, and Cieza never tried to conceal it, Markham's translation strategy makes the charges against them even stronger than they were, as in the following example, quoted in part by Diffie (1936, p. 100), in which the suicides committed by the natives out of their despair and hatred of the Spaniards are described as assassinations:

4. "Cuando entramos en este valle de Aburra, fue tanto el aborrescimiento que nos tomaron los naturales dél, que ellos y sus mujeres se ahorcaban de sus cabellos o de los maures, de los árboles, $y$ aullando con gemidos lastimeros dejaban alli los cuerpos y abajaban las ánimas a los infiernos" (Cieza, 1984, p. 120)

"When we entered this valley of Aburra, the detestation we conceived for the natives was such that we hung them and their women [literal translation: they and their women hanged themselves] to the boughs of trees by their hair, and, amid grievous moans, we left their bodies there, while their souls went down to hell" (Translation by Markham, 1864, p. 67)

This insistent downgrading of the Spaniards is also manifest in the manner in which the Incas are portrayed in Markham's translation. Diffie (1936, p. 101) shows statements indicating the despotic character of the Inca rule which are simply not translated. Bernstein and Diffie (1937, p. 552) also quote examples of this idealisation of the Indians in Markham's translation of Garcilaso de la Vega's Los Comentarios Reales de los Incas (1609), one of the key documents of the Spanish conquest. 


\section{The de Onis translation}

Harriet de Onis (1899-1969) ${ }^{6}$, a reputed translator of Portuguese and Spanish literary works into English - of the latter, among other books, she translated Gironella's The Cypresses Believe in God (1955), Palacio Valdes' José (1961) and Cervantes' Six Exemplary Novels (1961) translated Cieza's work in 1959 with the title The Incas of Pedro de Cieza de León ${ }^{7}$, edited by the ethnographer and archaeologist Victor Wolfgang von Hagen (1908-1985), a specialist in primitive American civilisations.

The volume includes photographs of places and objects mentioned in the narrative, a preface and an introduction by the editor, in which the translation's quality and integrity are commended:

And so to render the old naturalness of Cieza in a new way, Harriet de Onis, one of the finest scholar translators of our time, undertook to give Cieza that which he had not enjoyed in his four centuries of life[... ] without deletion and excised chapters "unfit for translation" (1959, p. viii).

Then, von Hagen explains why he has opted for the conflation of the first and second part, perhaps the most controversial feature of his edition, as well as for the omission of the first thirty-five chapters of the first part:

That "Crónica" published in Cieza's lifetime (1553) and the second discovered and published in 1880 , I found could be synchronised in one because the first is, in the main, geographical [...]; the second is concerned with the institutions of the Inca realm [...]. The first portion of the "Prima Crónica", that is, chapters I-XXXV, is about the land which is now Colombia, and as this was not within the Inca Empire, it has not been included in the present volume, being reserved for later publication (1959, p. ix).

Three other reasons for this conflation are explained in another paragraph: "[...] the excessive cost of publication, the desire to escape repetition, and

"An extremely comprehensive account of de Onís' life and significance as a literary translator is given by Balch (1998).

${ }^{7}$ The book is now out of print, according to the AAUP Online Catalog. 
the need to bring Pedro de Cieza's observations on the Incas into one available volume" (1959, p. viii). This last reason, perhaps the most principal and decisive one in terms of the edition, is not supported with further arguments.

The Incas of Pedro de Cieza de León is, therefore, a "digested" translation, whose main focus seems to be the description of the Inca Empire before the Spanish conquest, the subject of Cieza's second part of the Crónica. Von Hagen's ideological perspective with respect to the Spanish Conquest is not much different from Markham's, but his interest, more anthropological than historical, lies in the well-documented account of the ancient Peruvian civilisation carried out by Cieza:

This seventeen-year long journey gave countless generations the story of a people out of the reaches of time dwelling in the mountain fastness of the Andes and living a strange way of life which Cieza detailed in custom and history, describing their strange folkways and their destruction, which he chronicles even as they were being decimated and destroyed (1959, p. vii).

Although Stevens' and Markham's translations are criticised, Von Hagen feels the need of a new edition of these "Inca chronicles" (1959, p. vii), which can "avail itself, by explanatory notes, of all that is now known" $(1959$, p. viii). It goes without saying that the volume is profusely annotated with long and self-explanatory footnotes containing anthropological, geographical and historical details.

In this sense, both the title as well as the selection of chapters from the first and the second parts are sufficiently explicit: as we know, the first 35 chapters of the first part are omitted, because they describe Cieza's journey from Panama to Peru, considered irrelevant by Von Hagen, but the point is that another 37 chapters, from both the first and the second part, are nowhere to be found. As León $(1971$, p. 218) has suggested, this may be due to their repetitiveness, although sections of them are added to other chapters when their contents are related. This happens, for example, to chapter XXVII of the second part, which is added to chapter XCII of the first part without a note of explanation.

Sometimes (e.g. 1979, pp. 73, 91 and 108), whole sections are displaced from the main text and inserted in smaller characters in 
footnotes, perhaps in an attempt to reduce the cost of publication. Another procedure for indicating omissions is to insert lines of dots (...) at the end of a paragraph (e.g. 1959, pp. 53, 67 and 96).

All this reveals a conscious and powerful editing strategy, which seems to have determined all the decisions taken after, and probably before, the translation was finished. The abundance of editor's notes and the conspicuous absence of any translator's notes or preface are, in this sense, highly revealing.

\section{Conclusions}

In the above discussion, I hope to have shown how ideological, functional or even purely editorial reasons have shaped the English translations of the Crónica del Perú and, consequently, the reception of this key text of the Spanish colonization of America by Anglo-Saxon readership. In what follows, I will try to draw some conclusions, and connect them with specific historical and contextual aspects.

The first conclusion is that none of the three translations follows completely the "adequacy" principle to the ST, which is what normally happens when texts are highly respected in the source culture, or when this source culture is highly respected itself. This was, obviously, not the case of the Crónica, which had not been properly edited and published until the twentieth century even in Spain, whose decline in political and cultural terms was evident since the seventeenth century. The fact that the book was not properly valued in its own culture is important, if we consider the different translation policies followed with other Spanish "sacrosanct" books or "metanarratives" like Cervantes' Don Quixote or Lorca's poems and plays in the twentieth century. It is even more important to note the low value given to the role of Spain in the colonization of the Americas by Anglo-Saxon historiography on the subject. Mackenthun (1997, p. 5) traces this devaluation of the Spanish colonial system back to Perry Miller's famous preface to Errand into the Wilderness (1956), a key text of nationalistic historiography of postWorld War II United States, with the following words:

Miller's pervasive influence on the study of early American cultural history in the United States has for a long time blinded intellectual 
history to the insight that the exploration and colonization of America was a thoroughly transnational affair. Notably, the crucial role of Spain as both precursor and rival of English action has been neglected by the history of ideas $(1997$, p. 9).

The second conclusion is that each translation of the Crónica is a different historical product, influenced by different political and ideological agendas, which determine the levels of mediation of the translators. In this sense, Stevens' rendering reflects a low mediation, because it reproduces Cieza's own objectivity as a writer, despite its various omissions and some other interventions like the illustrations. His posture is condescending to Spanish methods of colonization, as expressed in the preface. The year of publication (1709) is in the middle of the Spanish War of Succession (1700-1713), when England and Spain were, theoretically, enemies. Two different pretenders to the Spanish throne, who were supported by different European powers, fought the war: Archduke Charles, a member of the Habsburg family, supported by Austria and England, and Prince Philip, a nephew of the French King Louis XVIII, supported by France and most of Spain's regions with the exception of Catalonia. The translator's preface, as shown above, commends the rules drawn up by the Spanish Habsburg kings of the sixteenth and seventeenth centuries in order to prevent abuses and cruelty to the American natives.

Conversely, Markham's translations were published in a period when loyalty to, or support for, the Spanish, was no longer necessary. The Spanish methods of conquest, considered cruel and barbaric by the Leyenda Negra, are severely criticised in the preface and carefully foregrounded in the translation, in order to establish a sharp contrast with the current British colonial system. Despite Markham's sincere respect for Cieza's objectivity and poise as a chronicler, his powerful ideological position shows both in the "Preface" and in his translation strategies, as described above. His aim, followed also in other translations, is to reinforce the stereotypical idea of Spain as a cruel and destructive colonial power. In this sense, the whole Hakluyt Society's nineteenth-century publishing policy seems to have adopted a political role, which was to 
remind the Victorian reading public of disgraceful colonial enterprises of the past at a moment of expansion of the British imperial system ${ }^{8}$.

Finally, the de Onis translation fulfils the purpose, perhaps more functional than ideological, of serving as a digested version of the first two parts of the Crónica for a reading public interested, above all, in the description of the Inca Empire, which is the subject of Cieza's second part. To achieve this, the editing, carried out by Von Hagen, omits chapters and "repetitive" passages in the name of readability, and conflates the two books into one, subverting Cieza's initial plan to assign each part a different subject. Although the anti-Spanish historical stereotype can still be found in the paratexts, it is not reflected in the target text through the translator's active intervention, as in Markham's case.

The three translations also reveal an overwhelming presence of the translator, in the case of the Stevens and the Markham translations, and of the editor, in the case of the Von Hagen edition. It is symptomatic that in this third and, so far, latest English translation of Cieza's Crónica, Harriet de Onís, the only woman translator, is praised, but completely silenced by Von Hagen's omnipresence.

In fact, none of the three translations reflected Cieza's work in its entirety, including some of its most relevant aspects, and all of them prompted justified, and sometimes angry, criticism. But, as mentioned earlier, not until very recently (1984) has the Crónica been given proper attention in its country of origin. A new and complete English translation, which can bring Cieza, the "Prince of Chroniclers", to the place he deserves, is definitely needed.

\section{Universidad de Málaga}

\footnotetext{
${ }^{8}$ In the "History and Objectives of The Hakluyt Society" contained in its WWW site, there is mention of their translation policy: "The English translation in which this material is presented is normally a fresh version, but in certain instances an earlier rendering which has been appropriately checked and if necessary corrected"(1998, p. 2). At present, all of Markham's translations are out of print, and they can only be found for sale in antique or second hand bookshops.
} 


\section{References}

1. Primary sources

1.1 Spanish editions

CIEZA DE LEÓN, Pedro de (1984). La crónica del Perú. Ed. Manuel Ballesteros. Madrid, Historia 16 (first published in 1553 and 1880).

CIEZA DE LEÓN, Pedro de (1985). Obras completas. Volumes I, II and III. Ed. Carmelo Sáenz de Santamaría. Madrid, Consejo Superior de Investigaciones Científicas.

CIEZA DE LEÓN, Pedro de (1985). El señorío de los incas. Ed. Manuel Ballesteros. Madrid, Historia 16 (first published in 1880).

CIEZA DE LEÓN, Pedro de (1986). Descubrimiento y conquista del Perú. Ed. Carmelo Sáenz de Santamaría. Madrid, Historia 16 (first published in 1946, 1958 and 1974).

\subsection{Translations in English}

CIEZA DE LEÓN, Pedro de (1709). The Seventeen Years Travels of Peter de Cieza, Through the Mighty Kingdom of Peru, and the Large Provinces of Cartagena and Popayan in South America: From the City of Panama, on the Isthmus, to the Frontiers of Chile. Tr. by Captain John Stevens. Printed in London.

CIEZA DE LEÓN, Pedro de (1864). The Travels of Pedro de Cieza de León, A. D. 1532-50, from the Gulf of the Darien to the City of La Plata, Contained in the First Part of his Chronicle of Peru. Ed. and tr. by Sir Clements R. Markham. London, Works, issued by The Hakluyt Society, vol. XXXIII.

CIEZA DE LEÓN, Pedro de (1883). The Second Part of the Chronicle of Peru, 1532-50. Ed. and tr. by Sir Clements R. Markham. London, Works, issued by The Hakluyt Society, vol. LXVIII. 
CIEZA DE LEÓN, Pedro de (1959). The Incas of Pedro de Cieza de León. Ed. Victor Wolfgang von Hagen. Tr. by Harriet de Onís. Norman, University of Oklahoma Press.

CIEZA DE LEÓN, Pedro de (1998). The Discovery and Conquest of Peru. Ed. and tr. by Alexandra Parma Cook and Noble David Cook. Durham and London, Duke University Press.

\section{Secondary sources}

AAUP Online Catalog. 27 January 1998. <press.chicago.edu/cgi/99/oklahoma/276.ctl>.

BALLESTEROS, Manuel (1984). "Introducción". Pedro de Cieza de León. La crónica del Perú. pp. 7-49.

BALCH, Trudy (1998). "Pioneer on the Bridge of Language". Américas, v. 50 n. 6 , pp. $46-51$.

BERNSTEIN, Harry, and DIFFIE, Bailey W. (1937). "Sir Clements R. Markham as a Translator". Hispanic American Historical Review 17, pp. 546-555.

BURTON, Richard, Sir (1886). "Terminal Essay". The Book of the Thousand and One Nights. London, Burton Club, pp. 63-302.

CASAS, Bartolomé de las (1994). Brevissima Relación de la Destrucción de las Indias. Ed. Jose María Reyes Cano. Barcelona, Planeta (first published in 1547).

CHILD, Jack (1992). Introduction to Spanish Translation. Lanham, University Press of America.

DIFFIE, Bailey W. (1936). "A Markham Contribution to the Leyenda Negra". Hispanic American Historical Review 16, pp. 96-103.

García Cárcel, Ricardo (1998). "Felipe II. La construcción de la leyenda negra”. El Semanal 540, pp. 32-33. 
GOLDBERG, Jonathan (1992). Sodometries. Renaissance Texts, Modern Sexualities. Stanford, Stanford University Press.

Hakluyt Society, The. 16 September 1997. <sas.ac.uk/Warburg/Hakluyt.htm>.

HERRING, H. (1965) A History of Latin America. New York, Knopf.

LEÓN, Pedro R. (1971). 'Pedro de Cieza de León, 'Príncipe Maltratado'. Breve estudio de las traducciones inglesas de la Crónica del Perú". Revista de Indias, pp. 125-126, 199-219.

MACKENTHUN, Gesa (1997). Metaphors of Dispossession. American Beginnings and the Translation of Empire, 1492-1637. Norman, University of Oklahoma Press.

MARTINELL GIFRE, Emma (1988). Aspectos lingüisticos del descubrimiento y la conquista. Madrid, C.S.I.C.

MARKHAM, Clements R, Sir (1864). "Introduction". Pedro de Cieza de León. The Travels of Pedro de Cieza de León... i-lvii.

ORANGE, Willem van (1980). Apologie of verantwoording van de prins van Orange. Nieuwkoop, Keureka (first published in 1580).

PÉREZ, Antonio (1676). Las obras y Relaciones de Antonio Pérez, secretario de Estado que fue del Rey de Espana, Don Phelippe Secundo. Colonia, Samuel de Tournes (first published in 1598).

STEVENS, John, Captain (1709). "Preface". The Seventeen Years Travel of Peter de Cieza... pp. 2-4.

SANTAMARÍA, José Miguel (1992). “Captain John Stevens”. Livius 1, pp. 211-219.

VON HAGEN, Victor Wolfgang (1959). "Editor's Preface". Pedro de Cieza de León. The Incas of Pedro de Cieza de León, vii-xii. 
WILLIAMS, Robert H. (1936). "A Manuscript Document On the Translations from Spanish by Captain John Stevens". Revue de Littérature Comparée 16, pp. 144-166.

\begin{abstract}
Translation and Historical Stereotypes : The Case of Cieza de León's Crónica del Perú - The Crónica del Perú (books I and II) by Pedro Cieza de León (1553) is one of the most systematic and objective descriptions of the Spanish conquest of America. It is also one of the best written. The book was first translated into English by Captain John Stevens in 1709, then by Sir Clements R. Markham in 1864 for the Hayklut Society, and finally by Harriet de Onís in 1959. However, none of these translations does justice to Cieza's magnificient work. While the two first translations are full of mistakes, acknowledged and unacknowledged omissions, as pointed out by Diffie, 1936; Bernstein and Diffie, 1937 and Pedro R. León, 1971, the third attempts a conflation of the two books into one, resulting in a confusing edition not devoid of misprints and inaccuracies. This paper attempts to show how the English translations of the Crónica, by way of unfortunate or deliberate manipulations aiming to obliterate the objectivity of Cieza's writing, have contributed to the reinforcement of the stereotypes which shape the "Black Legend" of the Spanish conquest of the New World. Stereotypes that, in the light of examples like this, perhaps need to be redefined.
\end{abstract}

RÉSUMÉ : Traduction et stéréotypes historiques : l'exemple de la Crónica del Perú (1553) de Cieza de León — La Crónica del Perú (volumes I et II) de Pedro Cieza de León (1553) offre l'une des descriptions les plus méthodiques et objectives de la conquête espagnole de l'Amérique. L'ouvrage a d'abord été traduit vers l'anglais par le capitaine John Stevens en 1709, puis par Sir Clements R. Markham en 1864 pour la Société Hayklut et finalement par Harriet de Onís, en 1959. Toutefois, aucune de ces traductions ne rend justice à l'œuvre remarquable de Cieza. Alors que les deux premières traductions comportent de nombreuses erreurs et omissions, admises ou non, comme l'ont signalé Diffie, 1936 ; Bernstein et Diffie, 1937 et Pedro R. León, 1971, la dernière, en voulant amalgamer les deux volumes, prête à confusion et comporte aussi coquilles et inexactitudes.

Cet article tente de démontrer comment les traductions anglaises de la Crónica, par des modifications malencontreuses ou intéressées visant à supprimer l'objectivité de l'œuvre de Cieza, ont contribué à renforcer les 
stéréotypes qui ont donné naissance à la « légende noire " de la conquête espagnole du Nouveau Monde. Des stéréotypes, qui, à la lumière des exemples cités, auraient peut-être besoin d'être revus.

Key words: translation, manipulation, history of Spain, stereotypes, Black Legend.

Mots-clés : traduction, manipulation, histoire de l'Espagne, stéréotypes, légende noire.

Juan Zaro: Departamento de Traducción e Interpretación, Facultad de Filosofia y Letras, Universidad de Málaga, 29071 Málaga, Spain. E-Mail : jjzaro@uma.es 